\title{
PARIS ON THE CHIGI VASE
}

CHIGI VAZOSU'NDAKİ PARİS

\section{TOM RASMUSSEN ${ }^{*}$}

\begin{abstract}
The exquisitely decorated Chigi Vase, made around $640 \mathrm{BC}$, is one of the best known of all Greek painted pots, and with its three intricate friezes with human figures it is certainly among the most ambitious ever produced at Corinth. Found in Etruria, it is not clear for whom it was originally made. It is easier to describe what it shows than to make firm statements about what it was intended to convey; most earlier discussions (usually very brief) have concluded that no linkage between the scenes was intended. Two more recent analyses, however, see an over-arching 'programme' at work, concerned with the paideia and training of Greek youths. The present discussion concentrates on the possible connections between the Judgement of Paris painted under the handle, and the other scenes, at the same time taking the remaining works of the Chigi Painter into consideration, and argues that the pot has more to do with Paris than previously thought.
\end{abstract}

Keywords: Greek Pottery • Corinth • Chigi (Vase) • Vase-Painting $\bullet$ Mythology
Özet: M.Ö. 640 civarında yapılan zarifçe süslenmiş Chigi Vazosu, tüm Hellen boyalı vazolarının en iyi bilinen örneklerinden biridir ve insan figürlü üç grift friziyle, kuşkusuz Korinthos'ta şimdiye kadar üretilen en iddialı vazolar arasında yer almaktadır. Etruria'da bulunan bu vazonun kim için yapıldı ğı belirli değildir. Neyi iletmek istediği hakkında kesin yargılar üretmekten ziyade vazonun neyi gösterdiğini tanımlamak daha kolaydır. En erken tartışmalar (genellikle çok kısa) sahneler arası bağlantı bulunmadığı yönündedir. Zira daha sonraki iki analiz, Hellen gençliğinin paideia ve bedensel eğitimle ilişkili olan eserde kapsayıcı bir program olduğunu gösterir. Bu çalışmada ise, kulbun altında resmedilen Paris'in karar sahnesiyle Chigi ressamının kalan eserleri dikkate alınarak incelenmekte, diğer sahneler arasındaki muhtemel bağlantılar üzerinde durmakta ve kabın önceden düşünülenden ziyade daha çok Paris'le ilişkili olduğu ileri sürülmektedir.

Anahtar Kelimeler: Hellen Seramiği • Korinthos • Chigi Vazosu • Boyalı Vazo • Mitoloji

Everyone knows the story of how Paris judged Aphrodite to be fairest goddess of all and how she in return rewarded him by introducing him to Helen whom he took back to Troy and so caused a famous war during which the losers of the beauty competition, Hera and Athena, would be implacably opposed to the Trojan cause. In Greek literature Paris cuts an ambivalent figure. Mocked by Hector for his beautiful looks and dubious military prowess (Hom. Il. III. 39-55), often preferring to fight with bow and arrow rather than a sword in the more conventional heroic manner (which is also the rather ignominious manner of his end), he is nevertheless prepared to force his way into the thick of battle, even challenging Menelaus to single combat - and when he is given divine protection at the last moment it is Aphrodite's choice not his. Later mythographers also tell of his bravery and prowess as a youth when beating off cattle-rustlers on Mount Ida (Apol. XII. 3.5) and hence justifying his alternative name 'protector of men'. Moreover, when his prize bull is seized

* Prof. Dr., School of Arts, Languages and Cultures, The University of Manchester, Manchester. tomrasmussen@talktalk.net 
and taken to be sacrificed at the annual games held - ironically - in honour of his own infant death, he follows it to Troy, and competing in the contests valiantly defeats all his royal brothers (Hyginus 91). At this point his true identity is revealed to him. Both Sophocles and Euripides wrote plays entitled 'Alexander' which dealt with aspects of his earlier years. Most sources are agreed that he was abandoned on Ida after his mother Hekuba's dream was interpreted to mean that the child she was bearing would prove to be a firebrand that would destroy the city, but there is some disagreement about whether Paris was his birth name and Alexander the name given by his rustic rescuer(s) or whether it was vice versa.

Given that this second-born son of Priam has many heroic qualities and that his part in the Trojan War is central, it is not surprising that he should appear early in Greek art. The most popular scene where he features is one that is given only the briefest mention by Homer: the judging of the three goddesses. This took place well before the events of the Iliad, and was recounted in the Kypria where it is clear that the goddesses were brought to Paris on Mount Ida. What is less clear is whether he was already accepted as a rightful prince at the time; if he was, then his status would be that of a royal herdsman ${ }^{1}$.

One of the first appearances of the scene is on the finest and perhaps best known of all Greek pots produced at Corinth, the Chigi vase of around 640 B.C. ${ }^{2}$. The scene, shown drawn out in fig. 1, is damaged but the subject is clear enough even without the inscriptions which name two of the goddesses as well as Alexander. Hermes, who had brought the divinities to the place of judgement, is entirely obliterated except for the tip of his caduceus. In these early depictions it is normal for the goddesses to be shown processing towards Paris, in later scenes the judgement is actually taking place. So far, no problem; more problematic is the relation between this tableau and the other scenes on the pot. These show (figs. 2-5), on the top register: two opposing armies about to meet in battle; middle register: next to Paris and the goddesses come riders and a charioteer, a double-bodied sphinx, a lion hunt; at the bottom a hare hunt (including a fox). There is also, between the upper and middle friezes, a narrow band of coursing dogs, deer, and wild goats picked out in white on the dark background.

The Chigi vase had found its way to Italy where it was buried in a tumulus outside the Etruscan city of Veii, and where it was excavated in 1882. This raises all sorts of questions which are simply impossible to answer. Was the pot used for a time at Corinth before being sent abroad? Was it used in Etruria before being deposited in a tomb? Was it made expressly for burial (abroad)? Was it a special order with precise instructions given concerning its decoration? These different scenarios must have a considerable bearing on what sense we are to make of the scenes it displays. To muddy the waters further, the inscriptions are written in a non-Corinthian, probably Aeginetan, script.

In an earlier brief commentary I remarked that in Greek vase painting apparently unrelated scenes do often occur on the same pot, and that in this example "there is no need to search for unity of theme at this early date even on such a rigorously planned work" decoration and choice of subject are unlikely to be purely random, as I noted later in a piece on the the subject matter of Greek pots: "presumably at the subconscious level the juxtaposition of scenes was

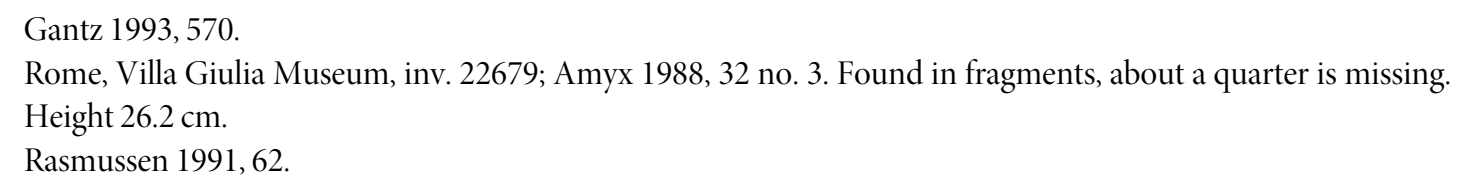




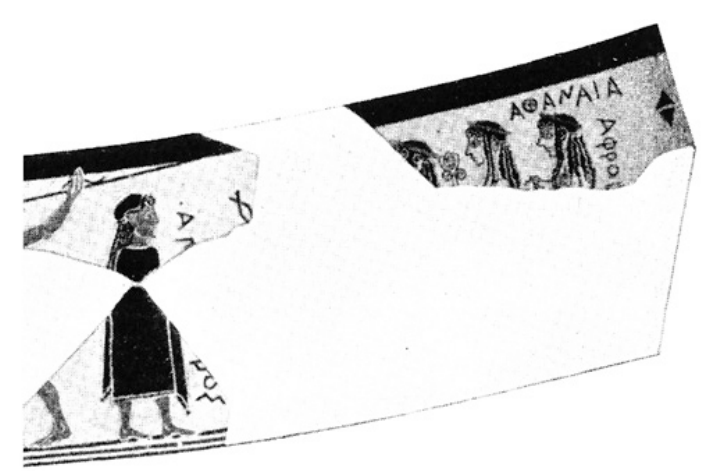

Fig. 1. Chigi Vase

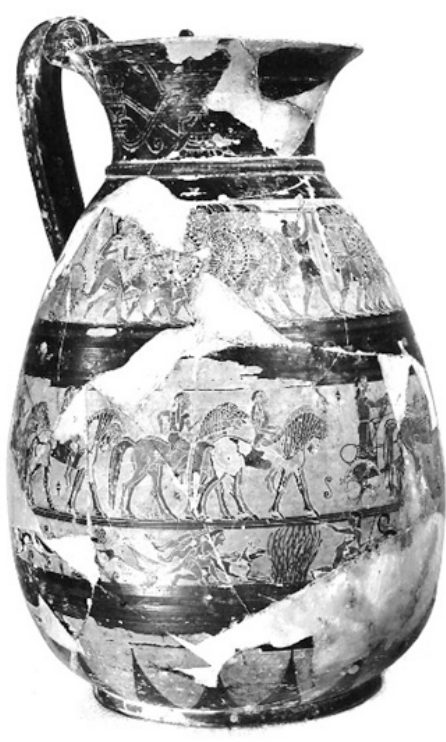

Fig. 2

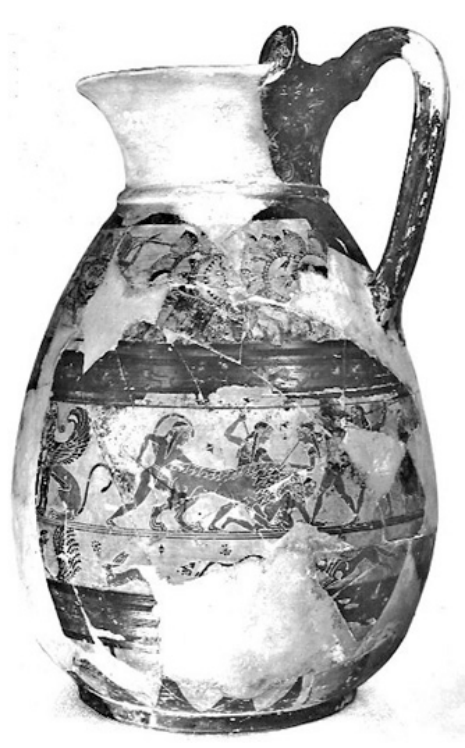

Fig. 3.

rarely arbitrary" ${ }^{2}$. As for rigorous planning, that is certainly in evidence here as it is for all blackfigure vase decoration, where incising into the clay involves an element of risk. As Michael Shanks has observed ${ }^{5}$, you could probably make good a mistake in painting by applying more paint, but incision is an irreversible commitment that demands you have a clear conception in your head before you start.

In the twenty-first century there have been two further commentaries on the vase, both of them quoting my words on the issue of unity of theme. Jeffrey Hurwit, whose analysis is the fullest to date, suggests ${ }^{6}$ that such a stance must inevitably lead to a position where the "painter knew what he was going to paint ... but he had no point to make" (a view I would not have fully accepted even when I wrote what I wrote). Mario Torelli's discussion ${ }^{7}$ comes as a kind of coda to an analysis of that other great work of early Greek black-figure, the François vase; he too is at pains to show that there is a unified programme here, moreover a programme that has 'moralising intent' ${ }^{8}$. Torelli also contrasts

\footnotetext{
Rasmussen 1996, 472.

Shanks 1999, 38.

6 Hurwit 2002, 16.

7 Torelli 2007, 11-13, 64-70.

8 Torelli 2007, 69.
} 


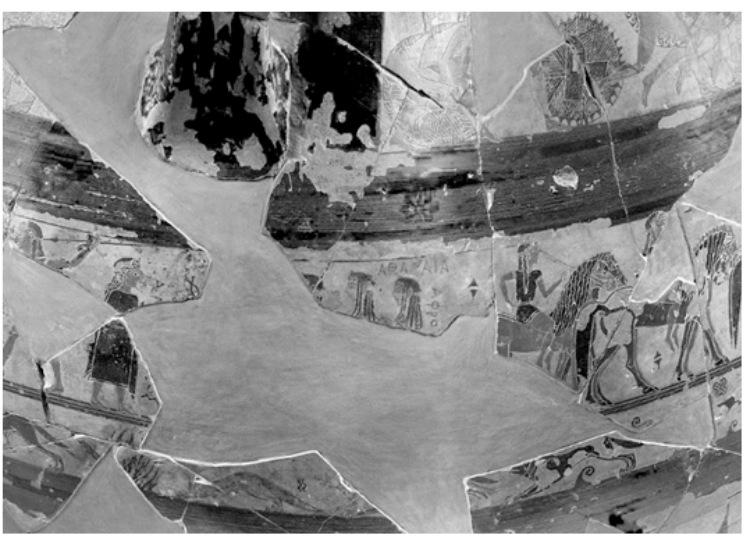

Fig. 4.

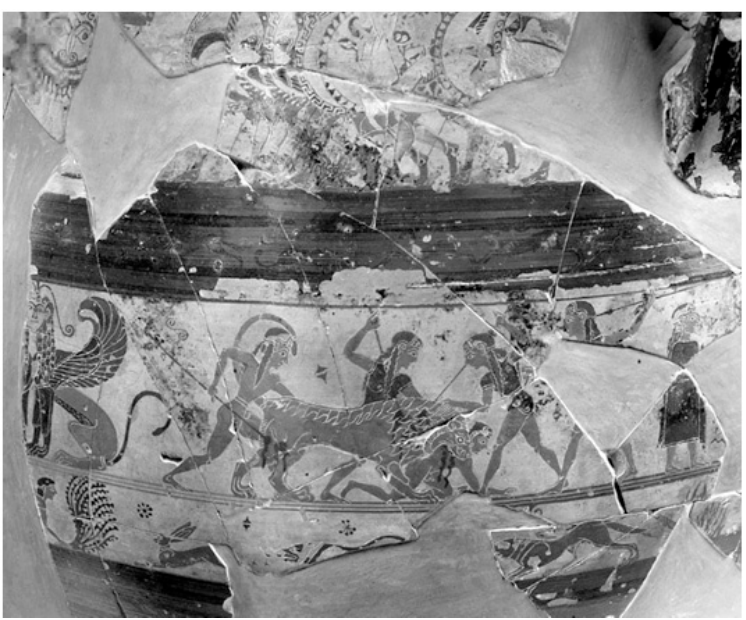

Fig. 5.

the creativities of the potters concerned. Certainly the François vase is 'eccezionale' for its shape, being the first surviving volute-krater; but the Corinthian vase is hardly 'del tutto di serie' ('completely run-of-the mill'), as it too is probably the earliest example of its kind, of a shape -the olpe- that was to be one of the most popular ever produced at Corinth.

It is not without interest to note how differently various commentators have assessed the visibility of the Paris group on the Chigi vase. Martin Robertson sees it as "tucked away under the handle at the back of the principal frieze", and Hurwit would concur ("this inconspicuously placed scene" $)^{10}$. But for Torelli it has a "strongly emphatic centrality", the emphasis being given by its linear axiality with the handle ${ }^{11}$. He also goes further: the Paris scene is alone inscribed in order to mark it off as the only mythical scene on the pot. Actually, he goes on to modify this view slightly (as we shall see).

Basically, Torelli and Hurwit agree about many things. The vessel's subject is about "a young aristos from Corinth" (Torelli), and 'reading' from the bottom up it shows the various stages that mark out his training from youth to adulthood. So hare-hunting is what you do as a child, warfare is for mature adults. It is the middle frieze that presents complications. The lion-hunting is unlikely to

\footnotetext{
9. Robertson 1978, 47

10 Hurwit 2002, 12.

11 Torelli 2007, 66 .
} 
be from real life, rather it seems (both agree) more derived from Assyrian royal hunting scenes, especially as the lion itself is in terms of style based on Neo-Assyrian types. Hurwit suggests that the lion-hunt and horsemen with chariot go together: the hunters may have dismounted from the riderless horses that are also in the picture, and in Assyrian depictions the hunting is often from horses and chariots. But actually this is problematic, as in Assyria the lion is always worsted (usually by the King himself) and never manages to bring down a human victim.

Given these difficulties it is little wonder that for Robertson the middle frieze presents "a series of disconnected scenes"12, for Amyx "a curious medley of subjects"13. At least the lowest and top friezes have, each of them, a unity of theme within themselves. To return to the horses and chariot, this scene can also be viewed in many other ways. They may be connected with the warfare shown above, the riders and charioteer in effect being squires to the fighting men. Torelli wonders whether the whole scene may be one of preparation for a grand procession at a religious festival. Whatever may precisely be going on here, the Hurwit/Torelli view is that the middle frieze depicts activities in which young men (between boyhood and maturity) might take part, even if the activity is unrealistically heroized in the case of the lion-hunt.

Into these sequences the Judgement of Paris is inserted. For such an insertion of a mythological scene into generic surroundings Torelli cites a parallel in the architectural terracotta relief plaques from Etruscan Acquarossa where two labours of Herakles are shown alongside scenes of military parade $^{14}$. However, on one plaque we see a chariot drawn by winged horses, so this is hardly in the realm of the everyday world.

Concerning the inclusion of the Judgement, Hurwit and Torelli are again in basic agreement. During the processes of growing up, the young Corinthian has difficult choices to make, and what is being underlined here is an example of wrong choice: of goddess (Aphrodite) and of life partner (Helen). However, Hurwit in addition airs the possibility that Aphrodite - despite the havoc she will wreak - is also being honoured as the goddess who has special status at Corinth.

Here it is worth bearing in mind that the Chigi vase is one of several painted by the same painter; they are mostly small unguent flasks (with decoration executed on an unbelievably tiny scale), but a fragmentary oinochoe from Erythrai may also be by his hand. According to mid-seventh century Corinthian conventions their surfaces are all divided into horizontal friezes, which may be tabulated as follows (working from the lowest to the uppermost figure frieze):

- London aryballos ${ }^{15}$ : hare hunt; riders; soldiers in battle.

- Berlin aryballos ${ }^{16}$ : hare hunt; animals; chariot race; facing armies.

- $\quad$ Oinochoe ${ }^{17}$ : coursing hounds; riders, lion hunt, sphinx, archer; battle scene, animals.

Closest to the Chigi olpe in subject matter is the Erythrai oinochoe, especially for its lion hunt where, here too, the lion has a prostrate victim at its mercy. It is a pity that the vessel is in such an incomplete state. Another close parallel to what is shown on the olpe is the opposing armies of the

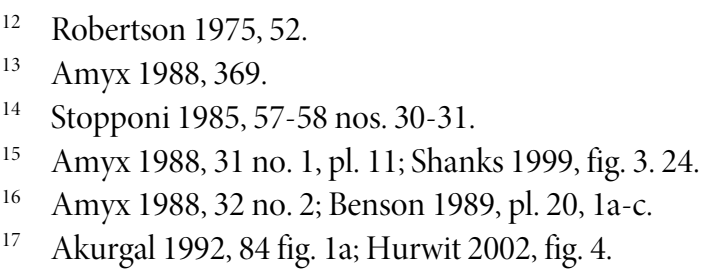


Berlin aryballos which likewise face each other over the very front of the vessel opposite the handle. In fact it should be apparent by now that much of the subject matter of the olpe is visible in the works listed above, if sometimes in more abbreviated form. One might even conclude that there was a formula at work here: hare-hunt at the bottom, something in between, fighting at the top. My postgraduate mentor of years past, Robert Cook, who was something of a spatial determinist ${ }^{18}$, might have suggested that battles and hunts were the kinds of subject that provided ideal scope for limitless expansion to fill encircling friezes, and that small animals (hares etc.) were suited to the exiguous space at the foot while larger human figures would best fit the area of maximum circumference. Or perhaps all these pots were intended to show a sequence of snapshots from male childhood to adulthood.

Robertson is not alone in regarding the Chigi vase as coming late in the painter's output, later than the aryballoi ${ }^{19}$. If then the 'formula' was already in place, why insert a specifically mythological scene into it? Whatever the reason, it will be argued here that the inclusion of the Judgement transforms the other scenes depicted and the whole ensemble. For a start, the setting for the hunting scenes is likely as not to be Mount Ida. Of all the many hare hunts on Corinthian vases, only this one, with its shrubs providing points of ambush, is at all concerned with setting and place. Moreover, it is one of the very few that include human figures. Paris' boyhood, we remember, was spent on the mountain, although we are told few details about it.

Before Paris' time there were other occasions of divine intervention on Ida. The first was when Ganymede was snatched up by Zeus to Olympus. The second, more relevant here, was the coupling of Aphrodite and Anchises. As the goddess made her way up the mountain, according to the Homeric hymn, there followed behind her all manner of great beasts - including wolves and lions ${ }^{20}$. Later, goddess and hero collapse upon his bed, on which "lay skins of bears and deep-throated lions which he had killed on the high peaks himself"21. Xenophon said that one had to go to 'foreign places' to hunt lions and is rather vague with his geographical indications ${ }^{22}$; but on Ida, in myth at any rate, there were lions for the taking. Here was another pastime for the youthful Paris, who in any case would need to defend his herds. It is true that neither the Cypria, which is the first literary account to set the Judgement on the mountain, nor the hymn to Aphrodite, need be earlier than the sixth century, but they are unlikely to be the first telling of the stories that include these particular details. In visual art, too, Paris as a herdsman is not seen before the remarkable Etruscan black-figure amphora in Munich of c. $540 \mathrm{BC}^{23}$, but then early Greek (and Etruscan) vase-painting of the previous century is scarcely concerned with physical setting at all.

The scene with riders and chariot has already been touched on. Clearly it has nothing to do with Ida, but it too can without special difficulty be connected with Paris' curriculum vitae - even if some of the relevant details are again supplied by late mythographers. One thinks of the games in which he took part and beat all comers, the preparations for them, the marshaling of personnel and equipment for the horse- and chariot-racing, and so on.

\footnotetext{
18 Cook 1964, 14-15.

19 Robertson 1975, 52.

20 Hes. Homeric Hymns 5 (to Aphrodite): lines 68-74.

Ibid. lines 158-160.

Xen. Cyn. 11.

23 Hannestad 1974, no. 1 pl. 1; Martelli 1987, no. 102.
} 
So we come to the warring armies in the upper frieze. It has long seemed to me most likely that an owner of the vessel would have seen such a monumental encounter in mythological terms, and most obviously in terms of the Trojan conflict. Torelli, too, briefly considers the possibility that this scene might 'in a broad sense be alluding to the Trojan War '- here shown 'updated ${ }^{24}$. The updating he doesn't elucidate further, but a clear example is the animated piper with his auloi. Piping is mentioned only twice in Homer and then not in a military context, nor can the use of the phorbeia (cheekstrap) be carried back further than the seventh century ${ }^{25}$. The 'hoplites', however, are not carrying the usual hoplite weaponry (short sword etc.) but are armed with a couple of throwing spears each. According to Hans van Wees, this may be a picture "either of close combat with the wrong weapons or of missile warfare at the wrong distance"26; and he goes on to compare the loose arrangement of the fighting groups with military episodes in the Iliad, in particular with the manoeuvres occasioned by the re-entry of Idomeneus into battle in Book 13.

The large double-bodied sphinx, not mentioned by Torelli, also needs to be considered. As a single-bodied example is also placed adjacent to the lion-hunt on the oinochoe from Erythrai, Hurwit may be right with his suggestion that there could be an intimation here of the impending death of the lion's victim ${ }^{27}$. On a shield band from Olympia of a couple of generations later, two confronted seated sphinxes are shown among other panels all of which depict scenes of conflict or carnage. Two of the victims are monsters (Nemean Lion and Minotaur), but mostly the violence is human on human ${ }^{28}$. Sphinxes do not have a single meaning in Greek art and culture, although later, especially at Athens, they will offer protective service as grave-markers. The double-bodied sphinx, a Corinthian speciality, must necessarily face out frontally, and so here mirrors the staring Gorgon's head on the hoplite shield in the frieze above which is in the same vertical axis for the viewer ${ }^{29}$. The combination may serve a protective, apotropaic function, which would be very appropriate for the olpe's final funerary destination. The tomb in question was certainly that of an Etruscan rather than an expatriot Corinthian, as other finds from it - including Etruscan inscriptions - make clear ${ }^{30}$.

Looking at the Chigi vase from bottom to top, then, we see that Paris can be involved in all of the scenes: in hunting, in preparation for games, in battle against the Greeks. It is not being proposed here that we should actually be able to identify him in these episodes, but that they may have provided the associations for the artist (at whatever level between the fully conscious and subconscious) to decide to insert the Judgement into their midst - into a series of scenes most of which he had tried out before. A vase which is essentially all about Paris would have far greater resonance for an Etruscan (and almost certainly for a Corinthian) than one displaying a series of images about the coming-of-age of a Corinthian/Greek youth. Etruscans were avid consumers of Greek mythology: only a decade or so later, around $630 \mathrm{BC}$, another olpe would be deposited in a tomb at the neighbouring city of Caere, this one of local bucchero fabric showing Daedalus and episodes connected with the Argonauts ${ }^{31}$. Later on, Paris (Etruscan: Elcsntre) would become one of

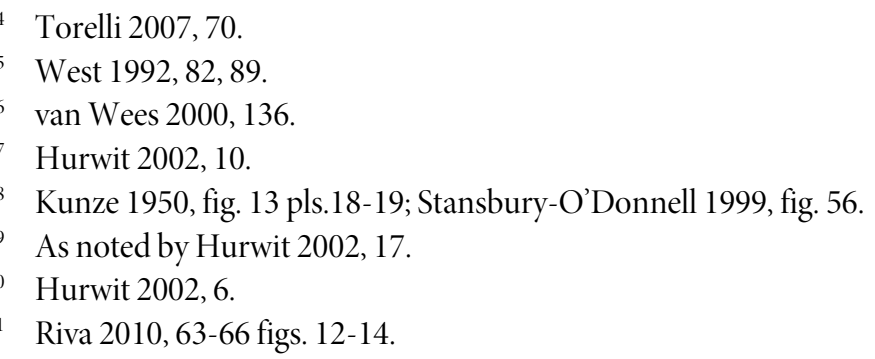


the most popular subjects in Etruscan art, especially on engraved mirrors.

Debates about the imagery of the Chigi vase have been given a vigorous kick-start by the analyses of Hurwit and Torelli, but a basic question of approach remains. Should one begin by formulating a general view about the subject matter and then try to fit the mythological episode into it, or is it better to work outwards from the known mythological characters? If the reasoning above is on the right lines, then this olpe is about the hero Paris qua hero, not about Paris as an object lesson in making disastrous choices. If, say, the sphinx had been placed adjacent to the Judgement and if the upper frieze had depicted massacres at the sack of Troy, then one might begin to wonder whether such a point was being made. But a Greek or an Etruscan looking at the imminent clash of opposing armies would surely have been stirred by the action, not shaken by the prospect of the horrors to come. It also seems very unlikely that any archaic vase-painter ever set out, or would ever have been instructed, to make with his pot a moralising statement; more likely that the object was to tell an entertaining story for its own sake.

\section{Figure Captions:}

Fig. 1. Johansen 1923, pl. 40.

Fig. 2. Soprintendenza per i Beni Archeologici dell' Etruria Meridionale

Fig. 3. Soprintendenza per i Beni Archeologici dell' Etruria Meridionale

Fig. 4. Soprintendenza per i Beni Archeologici dell' Etruria Meridionale

Fig. 5. Soprintendenza per i Beni Archeologici dell' Etruria Meridionale 


\section{BIBLIOGRAPHY}

Ancient Sources

Apol.

Homeric Hymns

Hom. Il.

Hyginus

Xen. Cyn.

Modern Sources

Akurgal 1992

Amyx 1988

Benson 1989

Cook 1964

Gantz 1993

Hannestad 1974

Hurwit 2002

Johansen 1923

Kunze 1950

Martelli 1987

Rasmussen 1991

Rasmussen 1996

Riva 2010

Robertson 1975

Robertson 1978

Shanks 1999

Stansbury-O’Donnell 1999

Stopponi 1985

Torelli 2007
(= Apollodoros, Bibliotheke)

Used with The Loeb Classical Library's text of Apollodorus, Bibliotheke, vols. I-II. Cambridge, vol. I. $2001^{9}$; vol. II. $2002^{9}$.

(= Homeric Hymnos)

Used with The Loeb Classical Library's text of Homeric Hymnos. Camb-

ridge, 1914.

(= Homeros, Iliad)

Used with The Loeb Classical Library's text of Homeros, İliad. Cambridge, 1924.

(= Hyginus, Fabulae)

Used with The Loeb Classical Library's text of Hygini Fabulae (1934) 1963.

(= Xenophon, Cynegeticus)

Used with The Loeb Classical Library's text of Ksenophon, Cynegeticus.

E. Akurgal, "Eine protokorinthische Oinochoe aus Erythrai". IstMitt 42 (1992) 83-96.

D. A. Amyx, Corinthian Vase-Painting of the Archaic Period. Berkeley, Los Angeles 1988.

J. L. Benson, Earlier Corinthian Workshops: A Study of Corinthian Geometric and Protocorinthian Stylistic Groups. Amsterdam 1989.

R.M. Cook, Niobe and her Children. Cambridge 1964.

T. Gantz, Early Greek Myth: A Guide to Literary and Artistic Sources. Baltimore, London 1993.

L. Hannestad, The Paris Painter. Copenhagen, Munksgaard 1974.

J. M. Hurwit, "Reading the Chigi vase". Hesperia 71 (2002) 1-22.

K. F. Johansen, Les Vases sicyoniens. Paris 1923.

E. Kunze, Archaische Schildbänder, OF 2. Berlin 1950.

M. Martelli, La ceramica degli etruschi. Novara 1987.

T. Rasmussen, "Corinth and the Orientalizing phenomenon". Eds. T. Rasmussen - N. Spivey, Looking at Greek Vases. Cambridge (1991) 57-78.

T. Rasmussen, “Ancient Greek Pottery: Subject Matter”. Ed. J. Turner, The Dictionary of Art 13. London (1996) 472-474.

C. Riva, The Urbanisation of Etruria: Funerary Practices and Social Change, 700-600 BC. Cambridge 2010.

M. Robertson, A History of Greek Art. Cambridge 1975.

M. Robertson, Greek Painting. Geneva 1978.

M. Shanks, Art and the Greek City State: An Interpretive Archaeology. Cambridge 1999.

M. D. Stansbury-O’Donnell, Pictorial Narrative in Ancient Greek Art. New York 1999.

S. Stopponi, Case e palazzi d'Etruria. Milan 1985.

M. Torelli, Le strategie di Kleitias. Composizione e programma figurativo del vaso François. Milan 2007. 
van Wees 2000

West 1992
H. van Wees, "The development of the hoplite phalanx. Iconography and reality in the seventh century". Ed. H. van Wees, War and Violence in Ancient Greece. London (2000) 125-166.

M. L. West, Ancient Greek Music. Oxford 1992. 